\title{
Women as Marginalized Sex in Alice Walker's The Color Purple
}

\author{
Aasif Rashid Wani \\ Research Scholar, Department of English, Sanchi University of Buddhist-Indic Studies, \\ Barla-Raisen (M.P.) \\ Akanksha Gupta \\ Ph.D. Research Scholar, Department of English, Dr Bhimrao Ambedkar University Agra (U.P)
}

\begin{abstract}
Indian writing in English is a literature produced by Indian authors who native or co- native of India similarly Afro-American literature produced by African authors in America. The authors like Philips Whitely and Olaudah Equiano, produced such a literature in the eighteenth century, they highlighted the slave narratives and the Harlem rebirth. But now there are many authors who produced an ample literature like Toni Morrison, Maya Angelou, Alice Walker, and Walter Mosley who are considered as the top writers in Afro- American genre. The specialty of this form of literature, they focused how black people were oppressed America. Through the novel 'The Color Purple' Alice Walker brought the suffering of black women into existence. Alice Walker's main intention was to highlight the sexual and racial issues and the struggle of women for survival. She depicted the problems of women on the demotic level. It represents the coercion and the use of black women, violence, subjugation and sexual exploitation. The main aim of this paper is to highlight the complicated life and sufferings of a female leading character Celie and other female characters in the novel who wants to freedom from society.
\end{abstract}

Keywords: Patriarchy, Sexual Oppression, Racism, Rape and Feminism.

DOI: $10.7176 / J L L L / 52-01$

\section{Concept of Feminism}

Feminism is a movement starts from west and spread like a fire in the whole world. The main aim of the feministic movement is to spread equality among both genders. Women have same rights like men in every field. It is a campaign of female rights, including right to vote, work with men in same office, they can receive same education, they became the owner of their property, and give protection to women and girl for sexual pestering. It is a movement which struggles against female suppression. Inside feminism there is also a group of women's in America who constantly fights against those people who suppressed the women. They also keep this thing in their mind that womanhood and race cannot be estranged. It should be always connected with each other. This movement in feminism is known as 'Black Feminism' in America both male and female from Africa suffered in terms of color, caste and ethnicity. The notion of subjugation entails "any unjust situation where, systematically and over a long period of time, one group denies another group access to the resources of society" (Collins, 4). ${ }^{1}$

The gender, color, culture, tradition and custom are connected with each other and form a particular class. In United States, Afro-American women's were not became the victim of suppression or oppression but the male society also became the sufferer of American culture. There was an extra facet of supremacy for AfricanAmerican women. So, women were mistreated not only by the hands of men but also by the hands of white women.

\section{Concept of Black Feminism}

From the time of enslavement in America, the greater part of African people has been suppressed. Suppressed is defined as "any unjust situation where, systematically and over a long period of time, one group denies another group access to the resources of society" (Collins, 5) ${ }^{2}$ Black suppression is divided into three different categories according to Patricia Hill Collins I-e ideological, economic and political facets of suppression. Afro-American women seriously affected by discrimination.

The chauvinistic, sexist and classist formation of American society break down into many racial groups, categories them as an inferior class on account of color. They are considered as an underclass society and they separate women from community on account of their gander. It a system where human being are discriminated or separated for their color or sex, which is highly objectionable, people were not treated as human beings in America, they thought that white color is their heritage and black people particularly women have no right to live on earth particularly in the united states. In India writing in English, it is the concept of 'Delit Literature' downtrodden people were also not allowed in temples also. They where suppressed by the hands of superior class. Many authors represented the life of tribal or downtrodden class in their respective works, in which they depicted how such people faced the problem in society. It is the system of asymmetrical power and freedom where human creatures are divided into many sects. "In the United States, racial segregation constitutes a 
fundamental principle of how racism is organized". (Collins, P.300) ${ }^{3}$. Black Feminism is the commendation that the color of women has been suppressed by sexism and racism. Neither they neither recognized the issue properly nor address this matter properly "Black Feminism focuses on the experiences, needs, and desires of women of color" (Aldridge 193) ${ }^{4}$

\section{The Color Purple as a Reflection of Society:}

Literature is tool for those peoples who don't express their problem in society. With the help of literature and other forms like theater, art, press they can express their struggle and efforts in the dominant group, in order to begin discourse about the racism, sexism and explain the other problem which they faced in their life. The position of Alice walker in Afro-American literature was so high; she was highly inspired by Zora Neale Hurston. Zora was an artist from Africa, America and also women. She was criticized everywhere. Her writing was admired and became inspiration for many authors. Alice Walker came to the point that she has to speak her thoughts in the form of writing. The development of her characterization is "incorrect enough to refuse to be measured by others' standards" (Winchell, 2) ${ }^{5}$. She begins her writing in inquest of our mothers. "To be an artist and a black woman, even today, lowers our status in many respects, rather than raises it: and yet, artists we will be" (Gardens, 237). ${ }^{6}$

The Color Purple is one of the outstanding works of Walker's. The novel is in epistolary form, set from the beginning of 1900 through the mid-1940s. We find the characters are became the victim of society in form of race or sex. A 14 year old girl Celie from south faced oppression from the male in the male dominated society, sexually abused by her stepfather. "You better never tell nobody but God. It'd kill your mammy" (CP 6) ${ }^{7}$ Alice Walker presented that her women characters are sufferers of violence. She also portrayed the journey of her characters from submission to self realization and attaining liberation. Carole J. Sheffield:

"The right of men to control female body is a cornerstone of patriarchy. Violence and the threat of violence against females represent the need of patriarchy to deny the woman's body of her own property". (Carole J. Sheffield) ${ }^{8}$

Throughout the novel her step father threatened her not disclose anything which is happening between her and her father Alphonso.

After the death of Celie's mother her father turned into more wild activities, before the death of his wife, he often used her stepdaughter, but the death of his wife; he raped again and again her daughter and made her pregnant twice. As she gave the birth top child he sold them and told her I killed them in a forest. Ultimately he got married with another woman and wants to through the burden from his shoulders, he married her to a man who is totally mismatched. Celie is enforced to marry a widowed grower with three Childs. Finally she got freedom from one wild creature but trapped into another. The society gave rights $t$ a man he can treat his wife as he like, he can abuse his wife as he wish. This is the cruelty of a society where women were discriminated. How they call themselves a man or superior, before marriage father is the protector and after marriage husband. In the case of Celie' everybody died and she is living under wild animals, because they don't know how to live or how to treat.

Still there is a hope of ray in her heart with the help of other loving women like Celie's sister, Nettie and husbands mistress Shug Avery; she learns that she is also a valuable woman in the world which develops her hope. Celie's cruel husband separate them before leaving, her sisters Nettie supported her for her activeness, it was love of sisters and both are female faced the same problem in the society, Nettie told to Celie: "You got to fight. You got to fight. But I don't know how to fight. All I know how to do is to stay alive."(CP 25) ${ }^{9}$. They wants remain in contact through letters, but unfortunately the husband of Nettie did not exposed any letter in front of Nettie. Celie always dropped letters and there is no hope but God.

The leading character Celie undergoes an outstanding change. She developed herself from hopeless, unhappy, oppressed, and abused by her father and her sheltering tree husband to start her own trade, owner of her own house and developed positive feelings which she never thought before. The most important transformation in her life that she narrated the traditional role of gender from opening to last pages of the novel "Initially, Celie believes that being a woman inescapably means that she has to serve and obey men and she is thus a victim of patriarchy. She is eventually introduced to another way of living by the strong female characters of Sofia and Shug who embrace her in a kind of sisterhood, which is a way for oppressed women to resist patriarchy". (Sundqvist, 2006, p. $12)^{10}$

\section{Concluding Remarks}

Therefore Alice Walker showed that women are a pictogram of optimism and renaissance for humankind and civilization. Alice Walker emphasized that American society is the society of racist and sexist society, where people became the victim of gender and sex with color. Husbands, fathers, lovers, brothers are the result of society who allow to those people, who oppressed to their sisters, mothers, daughter and wives. It is a 
contradictory novel, because it showed the strong elements of discrimination on account of sex, race and culture in South America where African black women became suffer in United States. The central character developed from ignorance to light. The theme of emancipation grows her desire and wishes in order to perk up.

"It also symbolizes the spirit of the black women, and her sexuality, bold and committed. Although far, more sensitive to social constrains and particularly those of race and class than the average white critic, black critics, too, saw the subject-black or white-as essentially free and as an autonomous moral agent, able to transcend the limitations imposed by time, place, and color. The relations between the white majority and black minority could be written interims of class relations, with the black minority kept subservient by ideology." In The Color Purple, the heroine, who ends as successful entrepreneur, stays within an individualist, capitalist frame and is therefore not full liberated". (Bertens, 2001, p 110) ${ }^{11}$

\section{Work Cited}

1. P.H. Collins, Black Feminist Though: Knowledge, Consciousness, and Politics of Empowerment. $2^{\text {nd }}$ Ed, New York and London: Rutledge, 2000. P 4

2. Ibid., 5

3. Ibid., 300

4. Delores P. Aldridge, Towards Integrating Africana Women into Africana Studies' Out of the Revolution: the Development of Africana Studies. Lanham: Rowman and Littlefield, Inc., 2003. P. 193.

5. Winchell, Donna Haisty. Alice Walker. New York: Twayne, 1992.p 2

6. Alice Walker, In Search of Our Mothers' Gardens: Womanist Prose. San Diego: Harcourt Brace Jovanovich, 1983. San Diego: Harvest/HBJ, 1984. P 237

7. Alice Walker, the color purple New York: Pocket Books, 1985. P 6

8. http://www.ijelr.in/4.1.17a/548-551\%20GURPREET\%20KAUR.pdf p. 549

9. Alice Walker, the color purpule New York: Pocket Books, 1985. P 25

10. S. Sundqvist, The Emancipation of Celie: The Color Purple as a womanist Bildungsroman. (Doctoral Dissertation, Karlstands University, 2006, p 12

11. Berten, H. literary Theory: The Basics. London: Macmillan press. (2001). 